\section{BA Institute of \\ YK Business Administration \\ तर Karachi \\ Leadership and Ideas for Tomorrow}

\section{Business Review}

Volume 5 Issue 1 January-June 2010

$1-1-2010$

\title{
The glass ceiling effect: A Pakistani perspective
}

\author{
Shandana Shoaib \\ Institute of Management Sciences, Peshawar \\ Romy Sajjad Khan \\ Institute of Management Sciences, Peshawar \\ Sajjad Ahmad Khan \\ Institute of Management Studies, University of Peshawar
}

Follow this and additional works at: https://ir.iba.edu.pk/businessreview

Part of the Business Administration, Management, and Operations Commons, and the Gender and Sexuality Commons

\section{(c) (i)}

This work is licensed under a Creative Commons Attribution 4.0 International License.

\section{Recommended Citation}

Shoaib, S., Khan, R. S., \& Khan, S. A. (2010). The glass ceiling effect: A Pakistani perspective. Business Review, 5(1), 79-90. Retrieved from https://doi.org/10.54784/1990-6587.1258

This article is brought to you by iRepository for open access under the Creative Commons Attribution 4.0 License and is available at https://ir.iba.edu.pk/businessreview/vol5/iss1/6. For more information, please contact irepository@iba.edu.pk. 


\title{
ARTICLE
}

\section{The Glass Ceiling Effect:} A Pakistani Perspective

Shandana Shoaib

Institute of Management Sciences, Peshawar

Romy Sajjad Khan

Institute of Management Sciences, Peshawar

Sajjad Ahmad Khan

Institute of Management Studies, University of Peshawar

\begin{abstract}
The Glass Ceiling commonly refers to impediments to career growth and upward mobility in organizations owing to racial and gender biases. The study undertaken on this phenomenon has reflected different behavior patterns for different factors leading to the glass ceiling effect. This paper focuses specifically on gender and analyzes the behavior pattern of women in Pakistani society. We have also analyzed the impediments and pressures that have resulted in creating a Glass Ceiling for women in higher management.
\end{abstract}

\section{Common Factors for Glass Ceiling Effect}

"According to the Federal Glass Ceiling Commission, Asian Americans were found to encounter an 'impenetrable glass' ceiling. Little is known about the determinants of their economic status and patterns of career mobility once they have entered the professional world",

The factors given by different research papers include stereotype, perceived minority status, psychological constraints of females, the employer's attitude, occupational choices, and family constraints. ${ }^{2}$

\section{Stereotype}

Stereotyping is a creating a set of beliefs about the characteristics or attributes of a specific character or role. The common stereotype about women is that their decisionmaking ability is weak. In contrast to this notion, their male counterparts in management are considered to have strong decision-making ability required at different levels within the organization. Therefore, this factor becomes a handicap for female employees to move up the higher managerial cadre. Women are hard workers, docile, and technically sound, therefore, they can be considered good workers but not good managers. This type of stereotyping has deprived women from climbing up the organization's hierarchy. The same holds true for Pakistani society. Male domination in Pakistani society has aggravated the situation for women thereby restricting their entry to higher levels of the organization. 


\section{Perceived Minority Status}

The application of the rule of "safety in numbers" is another factor responsible for creating a glass ceiling. Our findings indicate that females are perceived to be a minority in management, therefore, they are discriminated against. This strengthens the glass ceiling. This also has a psychological effect on career self-efficacy and development. Women start thinking that no matter how hard they work or no matter how proficient they are, they will hardly be considered for any top managerial post in the organization, leaving them constantly at the receiving end.

"In addition to those factors proposed by career development researchers, two psychological constructs are relevant to predicting how Asian Americans may be affected by and react to stereotyped situations. The first psychological concept is stigma consciousness, which refers to individual differences in the extent to which a target of a stereotype expects to be stereotyped by others, and this has consequences on the subsequent behavior of the target and also on interpersonal interactions. Individuals differ as to their perceptions of the probability of being stereotyped, which could have important implications for how targets experience and behave in stereotype-relevant situations. Stigma consciousness is relevant to the target's expectation of being stereotyped, regardless of the target's actual behavior. Individuals belonging to the same stereotyped group do not all experience their stereotyped status in the same way, and this is related to their individual level of stigma consciousness." 3

The first psychological concept is stigma consciousness. According to this concept the deviation of the individuals from their stereotyped role results in unacceptability of that new role to other individuals. Under the circumstances that individual is looked down upon by others creating a painful psychological effect for the target individual. Women are usually more prone to social pressures and any such painful experience drastically affects their performance.

Stigma consciousness thus deals with the target's expectation of being stereotyped, ignoring the aptitude and attitude of the target individual. In Pakistani society, certain occupations in which there is frequent interaction with the opposite sex is usually regarded in a negative light and women in such positions are stigmatized. This attitude could be detrimental to women's career, as they would forego opportunities that will provide the necessary impetus for obtaining managerial posts. ${ }^{4}$

Such females are happy with the status quo, irrespective of their high level of competence. "Individuals high in stigma consciousness will avoid stereotype relevant domains: that is, forgo opportunities to invalidate stereotypes about their groups." 5

Different female groups experience varying types and degrees of stereotype threat (victimization) because the stereotype about them differs in content, scope, and 
in the situation to which they are applicable. Stereotype threat is the greatest to women in managerial positions in Pakistan. Any failure or wrong decision is immediately associated with the gender factor, i.e. female, without probing into the root cause or giving her any chance of defense that may go in her favor. This curtails the chances of consideration of female staff for promotion into higher management. ${ }^{6}$

Statistics show that the employers, both in the public and private sector, are hesitant to promote women employees to the top most positions in their organizations. Several reasons have been put forward but the main reason is that women lack the requisite knowledge, skills and experience for such type of posts. In many cases the reason may be that they are reluctant to get significant exposure, which could result in enriching their knowledge, skills and experience. Thus women lag behind in the race for top slot. ${ }^{7}$

A similar study in America's largest companies has revealed that women have been pushed to the wall as almost 95 percent of the top posts are held by male managers. These are the figures in one of the world's most advanced nation where the struggle for equal opportunities has strong advocates of the premise of Equal Employment Opportunities (EEO). In Pakistan, women hardly make up a fraction of the workforce who have succeeded to or believed to have crossed the line and entered into the top levels of the organization. ${ }^{8}$

\section{Occupational Choice}

Researchers have found that due to negative stereotyping women are left with no choice but to go for technical jobs and hard sciences, i.e., physics, chemistry, and computer science. They try to shun fields that involve more social interaction and are hesitant to join such fields and pursue a career in the same. The result is obvious i.e., under-representation of female in the social sciences and the other related disciplines.

"There is a pattern of education facilitating entry into professional fields, overrepresentation in the technical fields, and under-representation in managerial and executive positions in the high technology and corporate worlds." 9,10

In Pakistan, despite the fact that women are educated in social or management sciences, their occupational choice is academia or office desk jobs. The fear of resistance in the management field, specially associated with gender, is so high that they are compelled to make a choice, which they hardly relish.

\section{Work Environment}

Women, when placed in the management sector of an organization are kept suppressed by offering fewer incentives as compared to the male staff of the same status, 
causing a feeling of alienation among them right from the beginning. This takes a great deal of effort on their part in maintaining their existing position rather than attaining a higher position in the organization.

One of the organization's strategies to grow and develop is to design a viable system of human resource management in order to attend to the problems of its employees. Women benefit from this strategy only if the organization is willing to accept the glass ceiling as a "problem"- which is rare. At the end of the day, women are compelled to live with the status quo rather than seek a solution. This not only lowers their output but also results in negatively affecting their reputation in their professional field and tends to become an impediment to their promotion. Furthermore, their male counterparts hold most of the top management positions therefore, they either do not understand female problems regarding this issue or act indifferently towards them or don't give it the serious consideration it deserves.

\section{Family Commitment}

Women are hard pressed on time. In order to become a CEO or find a place in the top management slot requires at least seventy to eighty work hours per week or twelve to thirteen hours of work daily. For most women family takes priority over all matters. Thus, the job takes a secondary place in her life. On the contrary, it is commonly seen that her male counterpart is supported in every aspect so that he can work well. This fortifies the glass ceiling.

\section{Diversity in Staff and Diversity of Style}

Subjectivity in the hiring process manifests itself in the search for candidates with "leadership" and "communication" skills. The evaluator's own role models help construct the mental image of leadership. Moreover, these qualities cannot be quantified, thereby, women easily fall prey to biases at the hands of the managers.

One of the most important factors considered in the hiring process is whether or not a candidate would comfortably in the organization culture. At this point male candidates are considered a natural fit in any organization. Such an evaluation is usually made by the authority that will in future be working closely with the female if she is selected. The evaluators are usually men from the highest echelon of the organization. Therefore, they are prone to keep the management team free from gender diversity. Some female candidates have smashed through the glass ceiling and have crossed this barrier but such cases are very atypical and are very few in number. ${ }^{11}$

"While some of this imbalance has likely improved in the years since, it remains today almost always big news when a woman or a racial minority becomes CEO of a large corporation. Conditions in the government sector are not so different. Although 
more women and members of at least some minority groups hold leadership roles in government, there are far fewer than would be available in the labor force, and the under-representation remains pretty pronounced.", 12

Even in the developed countries partial success has been evidenced after years of fight against this imaginary barrier-the glass ceiling. Although, women have been recruited in many organizations both in the private and public sector, yet their careers have stagnated at the lower and middle levels of management. They have actually encountered the glass ceiling in the later stages of their career. In Pakistan, very few women have overcome the glass ceiling but the barrier remains intact for others. Those few who have somehow reached to the top positions can be counted on fingers.

In addition to the glass ceiling, women have also encountered similar other problems. These problems have been an extension of the glass-ceiling concept, which include "Glass Walls", "Sticky Floors" and "Trap Doors".

"Glass walls" propel women into those career paths that lack the potential of advancement to upper slots. As the woman is seen only as a player of a specific role, therefore, her entrance into higher career role is restricted within "glass walls".

"Trap Doors" refers to the problems of women in their workplace, e.g., sexual harassment, about which they would rather keep quiet than speak out due to fear of defamation. If a female employee files a case against such an act it would mean letting more people know about that embarrassing and disturbing incident thus aggravating the problem rather than solving it. Such a situation encourages men to continue to exploit women.

"Sticky Floors" refers to transitional positions such as "administrative assistant", where employees are kept and prepared for vertical movement in the organizational hierarchy. Females, while working in such transitional positions are denied the access to necessary professional training and development that will help them excel in their profession and advance into managerial positions. While analyzing the gender disadvantaged group in the senior management ranks, we found that some of the factors responsible for the glass ceiling effect could be traced to the lower priority given to the professional development of the female at the early stages of her career.

The report prepared by the International Labor Office (ILO) for the International Women's Day depicts the bleak picture of the status of women. The facts and figures given in this report are shocking. If the figures continue to remain the same it will become almost impossible to achieve the Millennium Development Goals of reducing poverty by almost 50 percent in the year 2015 . As reduction of poverty does not mean that such a relief takes place in only male working class, therefore, the targets of poverty alleviation will not be achievable unless a holistic approach is considered. 
The report also reveals that females are paid less even in those jobs that are usually regarded as typical female occupations, such as nursing and teaching. The employer is aware that opportunities for women are very few therefore, they compel women to work for less compensation. ${ }^{15}$

"Lower returns on education, as evidenced by lower salaries, lower likelihood of promotions into managerial positions, and lower power and authority in managerial positions, especially in the higher end professional and technical fields, seem to support the existence of a glass ceiling for Asian Americans." 13

According to a survey, "The (females) represent 60 percent of the world's 55 million working poor. At the same time the rate of success in crashing through the invisible, symbolic barrier to top managerial jobs remains 'slow', uneven and sometimes discouraging", 14

The overall picture has been grim. Women are struggling to shatter the glass ceiling and enter the managerial level posts in organizations but all this is happening at a snail's pace. In Pakistan too, women have been entering the top levels of the organization, but at a very slow pace. Moreover, the percentage of such women is negligible.

\section{The Seven Basic Moral Principles for Management}

\section{Dignity of human life}

The lives of people are to be respected. Human beings by the fact of their existence, have value and dignity. We may not act in ways that directly intend to harm or kill an innocent person. Human beings have a right to live; we have an obligation to respect the right to life. Human life is to be preserved and treated as sacred. ${ }^{16}$

Drawing upon this principle, female section of the population is an integral part of the Human life and therefore, should be respected just as the male section of the population. According to this principle the society is obligated to honor the rights of women as imperative for their existence.

\section{Autonomy}

All persons are intrinsically valuable and have the right to self-determination. We should act in ways that demonstrate each person's worth, dignity, and the right to free choice. We have a right to act in ways that assert our own worth and legitimate needs. We should not use others as mere things or only as a means to an end. Each person has an equal right to basic human liberty, compatible to a similar liberty for others. ${ }^{17}$ 
Again applying the rule of autonomy, it is strongly advocated that the realization of the right to freedom of choice is as important for females as for males. This right should not only be agreed in principle, as it exists today, but should also be integrated as a crosscutting theme.

\section{Honesty}

The truth should be told to those who have a right to know it. Honesty is also known as integrity, truth telling and honor. One should speak and act so as to reflect the reality of the situation. Speaking and action should mirror the way things really are. There are times when others have the right to hear the truth from us; there are times when they do not. ${ }^{18}$

Honesty so proposed in this principle should be reflected in our actions as well and, therefore, implementation of the rules promoting equality irrespective of the gender biases should be sought.

\section{Loyalty}

Promises, contracts, and commitments should be honored. Loyalty includes fidelity, promise keeping, keeping the public trust, good citizenship, and excellence in quality of work, reliability, commitment, and honoring just laws, rules, and policies. ${ }^{19}$

Similarly, the principle of loyalty should be applied with a strong commitment to promote the right to equal opportunity in true spirit. This supports the fact that if females are eligible to excel in life, they should not be denied this right and should be trusted just like their male counterpart.

\section{Fairness}

People should be treated justly. They have the right to be treated fairly, impartially and equitably. We have an obligation to treat others fairly and justly. All have the rights to the necessities of life-especially those in deep need and dire helplessness. Justice includes equal, impartial, and unbiased treatment. Fairness tolerates diversity and accepts differences in people and their ideas. ${ }^{20}$

It applies as well to the female section of the workforce. This principle supports that female should be given fair chance to excel in their career and should be considered as equal candidates for promotions to higher slots as their counterparts.

\section{Humanity}

It comprises of two parts: (1) Our actions ought to accomplish good, and (2) 
avoiding evil. We should do good to others and to ourselves. We should have concern for the well being of others and show this concern in the form of compassion, kindness, and caring. ${ }^{21}$

Denying such a treatment to women results in the creation of an incomplete human society. Taking this a bit further, an organization should be as sensitive to female problems as they are to the problems of their male staff so as to increase their output. They should support females to further their career as they do for the male staff.

\section{The common good}

Actions and decisions should accomplish the "greatest good for the greatest number of people. One should act in ways that benefit and ensure the welfare the largest number of people, while trying to protect the rights of the people." ${ }^{22}$

This principle not only implies that large number of the same group should be taken into account, but in fact, it favors diversity. Therefore, it takes into consideration all the associated groups. This means that the female interests and rights should also be safeguarded though they exist in minority at the workplace. The organization's policies should be so designed that they do not make them feel stranded at the workplace.

\section{Some Suggestions to Shatter the Glass Ceiling}

In order to shatter the glass ceiling the first thing to be done is to bring a positive change in the Pakistani society. Positive change means a shift from our orthodox values which place women in the passenger seat of the of the society vehicle. They should be given responsible positions in the top-level management and allowed freedom to make decisions that can best serve their organization. This will bring confidence in their abilities. It will also eliminate the negative stereotyping that women are incapable of decision making.

"A seventy- or eighty-hour work week is commonplace for CEOs, and many in this field believe that women are not willing to make that time commitment because their role in the family is to provide a second income and be the primary caretaker of the couple's children. In addition, many women choose not to build the foundation that would qualify them for upper management. For instance, women need an advanced education and need to willingly accept work duties that include making difficult choices, taking risks or performing unpleasant tasks. Oftentimes men adopt an attitude that women deserve lower pay because they simply don't perform as well as their male counterparts. Moreover, men attribute women's failure to a lack of understanding of the corporate structure and cite this as their biggest stumbling block." 23 
"Authors like Dr. Edward H. Clarke avidly argued against women working in America. He claimed that women who exerted energy away from their reproductive organs and into their brain would threaten their health and their ability to create children (Drachman 38)."24

Moreover, women also need trust and support from their families, especially from their spouses so that she can work whole heartedly and climb the rungs of the organizational hierarchy.

"Under-representation" of women at the most rarified heights of business is a result of conscious decisions and overt anti-women prejudice on the part of company's CEO and board of directors. Other, somewhat more generous critics see the dearth of female business leaders as an inexorable result of subconscious prejudice: the psychological and cultural fallout of years of male domination in our society. In either case, once again the Siren call for Federal intervention to "correct" such "inequities" echoes across the political landscape. ${ }^{25}$

Female employees should be treated at par with their male colleagues not only in provision of opportunities but also in being rewarded for their performance. Employees should be rewarded on the basis of their contribution to the organization in terms of achieving its goals and not on the basis of gender. If a female employee is contributing more than the male employee, she should not be deprived of the opportunity to earn more. ${ }^{26}$

More specific to the Pakistani society is the stigma attached to certain occupations where a great deal of interaction takes place with men. The Pakistani society needs to change this mind-set. This will allow women to join any occupation and any organization of their choice if they are capable enough. It will also pave the way for entry into highlevel positions.

Women should also fight for their rights rather than beg for them. They should have well defined goals for themselves. They should be committed towards their career and be ready to put in all that it takes to excel in their careers and thus shatter this barrier.

This is just the tip of the iceberg. There are several other issues that have to be addressed before the glass ceiling can actually be shattered. If women can be responsible for bringing new life in this world, they can be expected to hold any sort of responsibility. It is only the wrong perception of men that females are weak and cannot take the responsibility of decision making at higher levels within the organization.

\section{Conclusion}

In the present study we found little evidence of advancement of women in higher management. None of the organizations presently operating in North West Frontier 
Province (NWFP) has a majority of women on their board of directors and at the executive level. Gender, race and minority discrimination prevails in our society in different forms, e.g., denial of career opportunity, job segregation, and lack of promotion opportunities. According to 1998 census survey of Islamic Republic of Pakistan the literacy rate of Pakistan is $43.92 \%$ of which $54.81 \%$ are males while $32.02 \%$ are females. This indicates that gender discrimination prevails in provision of education which lays the foundation for the prosperity and development of country. ${ }^{27}$

In other words, there is a very small percentage of women working in high ranking positions in the company while a majority of the companies prefer to have men in top positions.

This study shows that the glass ceiling is firmly in place. It is even more disturbing that studies of other companies show that most CEOs believe that the glass ceiling is no longer a problem. ${ }^{28}$ At least partially as a result of this perception, most companies do not make an effort to recruit women to top positions and tend not to rate their top officers on their ability to create equal employment opportunities. ${ }^{29}$

As long as the existing practices and misconceptions do not change, the rate at which women advance into top positions is not likely to change either.

In order to break the glass ceiling, Rene Redwood, assistant to former Labor Secretary Robert Reich, recommended that CEOs set recruitment goals and then measure, monitor and tie evaluation and rewards to employees' ability to meet these goals. ${ }^{30}$

These objectives, she argued, should include recruitment outside typical networks and thinking about alternative experience and non-customary backgrounds for employment. She also recommended establishing networking and mentoring opportunities for women already in corporations and creating a work environment welcoming women by adopting policies that are conducive to balancing work and family responsibilities such as flexible hours and telecommuting opportunities. ${ }^{31}$

Studies also show that companies with women in top management positions also tend to do better. A 1993 study of Standard and Poor 500 companies showed that firms that succeed in shattering their own glass ceilings racked up stock market records that were nearly two and half times better than otherwise-comparable companies. ${ }^{32}$

Therefore, for development and economic stability of the country it is important that the glass ceiling is removed and women are given optimum opportunities to advance in the organizational hierarchy. 


\section{Foot Notes}

${ }^{1}$ Wong, P. and Nagsawa, R. (1991) “Asian American Scientists and Engineers: Is There a Glass Ceiling for Career Advancement?" Chinese American Forum, 6(3), pp 3-6. 2 Pinel, E. C. (1999). Stigma consciousness: The psychological legacy of social stereotypes. Journal of Personality and Social Psychology, 76, pp 114-128.

2 Pinel, E. C. (1999). Stigma consciousness: The psychological legacy of social stereotypes. Journal of Personality and Social Psychology, 76, pp 114-128.

3 Pinel, E. C. (2002). Stigma consciousness in intergroup contexts: The power of conviction. Journal of Experimental Social Psychology, 38, pp 178-185.

${ }^{4}$ Leong, F.T.L. \& Hardin, E. (2002) Career Psychology of Asian Americans: Cultural Validity and Cultural Specificity. In G. Hall \& S. Okazaki(Eds.), Asian American Psychology: Scientific Innovations for the 21st Century (pp. 131-152). Washington, D.C. American Psychological Association.

6 Pinel, E. C. (1999). Stigma consciousness: The psychological legacy of social stereotypes. Journal of Personality and Social Psychology, 76, pp 114-128.

${ }^{7}$ Ibid

${ }^{8}$ Pinel, E. C. (1999). Stigma consciousness: The psychological legacy of social stereotypes. Journal of Personality and Social Psychology, 76, pp 114-128.

9 Duleep, Harriet Orcutt, and Seth Sanders. 1992. "Discrimination at the Top: American-Born Asian and White Men." Industrial Relations 31 (3): 416-32.'

${ }^{10}$ Tang, Joyce. (1993). "The Career Attainment of Caucasian and Asian Engineers." Sociological Quarterly 34 (3): pp 467-96.

11 Paul Igasak. (2005) The Glass Ceiling: Roadblock to Promotions By From IMDiversity.

12 Paul Igasak. (2005) The Glass Ceiling: Roadblock to Promotions By From IMDiversity.

15 Mitra, Subhashis. New initiatives in urban poverty alleviation. PTI Economic Service,38(3),Feb 1, 2006. pp. 36-38.

13 U.S. Glass Ceiling Commission (1995). A Solid Investment: Making Full Use of the Nation's Human Capital (Final Report of the Commission). Washington, DC: U.S. Government Printing Office.

${ }^{14}$ Mitra, Subhashis. New initiatives in urban poverty alleviation. PTI Economic Service,38(3),Feb 1, 2006.p.36-38.

${ }^{16}$ Dharmic Management: A Concept-Based Paper on Inner Truth at Work Hawley, Journal of Human Values.1995; 1: pp. 239-248.

17 Ibid

18 Dharmic Management: A Concept-Based Paper on Inner Truth at Work Hawley Journal of Human Values.1995; 1: pp. 239-2488.

19 Ibid, ${ }^{20}$ Ibid, ${ }^{21}$ Ibid

22 Dharmic Management: A Concept-Based Paper on Inner Truth at Work Hawley Journal of Human Values.1995; 1: pp. 239-248.

23 Dr. Edward H. Clarke (2002) "Shattering the Legal Glass Ceiling"

24 Dr. Edward H. Clarke (2002) "Shattering the Legal Glass Ceiling"

25 Dr. Edward H. Clarke (2002) "Shattering the Legal Glass Ceiling"

${ }^{26}$ Shattering the Glass Ceiling by Russell Maddan (Originally Published online in SpinTech, 3-12-00).

27 Population census organization: 1998 CENSUS7

28 Rene Redwood, The Glass Ceiling (Working Woman's Summit, 1996 [cited July 21, 2003]).

29 "Good for Business: Making Full Use of the Nation's Human Capital," (Washington, D.C.: Federal Glass Ceiling Commission, 1995).

31 Ibid

32 Ida L. Castro, "Should Women Be Worried About the Glass Ceiling in the Workplace?," Insight on the News, February 10, 1997. 


\section{References}

U.S. Glass Ceiling Commission (1995). A Solid Investment: Making Full Use of the Nation's Human Capital (Final Report of the Commission). Washington, DC: U.S. Government Printing Office. http://digitalcommons.ilr.cornell.edu/key_workplace/120

Wong, P. and Nagsawa, R. (1991) "Asian American Scientists and Engineers: Is There a Glass Ceiling for Career Advancement?" Chinese American Forum, 6(3), pp. 3-6.

Pinel, E. C. (1999). Stigma consciousness: The psychological legacy of social stereotypes. Journal of Personality and Social Psychology, 76, 114-128

Pinel, E. C. (2002). Stigma consciousness in intergroup contexts: The power of conviction. Journal of Experimental Social Psychology, 38, 178-185

Leong, F.T.L. \& Hardin, E. (2002) Career Psychology of Asian Americans: Cultural Validity and Cultural Specificity. In G. Hall \& S. Okazaki (Eds.), Asian American Psychology: Scientific Innovations for the 21st Century (pp. 131-152). Washington, D.C. American Psychological Association.

Duleep, Harriet Orcutt, and Seth Sanders. 1992. "Discrimination at the Top: AmericanBorn Asian and White Men." Industrial Relations 31 (3): 416-32.

Tang, Joyce. (1993). "The Career Attainment of Caucasian and Asian Engineers." Sociological Quarterly 34 (3): 467-96.

Paul Igasak. (2005) The Glass Ceiling: Roadblock to Promotions, By From IMDiversity,

Mitra, Subhashis. New initiatives in urban poverty alleviation. PTI Economic Service, 38 (3), Feb 1, 2006, pp.36-38.

Dr. Edward H. Clarke (2002) "Shattering the Legal Glass Ceiling"

Shattering the Glass Ceiling by Russell Maddan (Originally Published online in SpinTech, 3-12-00)

Population census organization: 1998 CENSUS

Rene Redwood, The Glass Ceiling (Working Woman's Summit, 1996 [cited July 21, 2003]). Available from .

"Good for Business: Making Full Use of the Nation's Human Capital," (Washington, D.C.: Federal Glass Ceiling Commission, 1995).

Ida L. Castro, "Should Women Be Worried About the Glass Ceiling in the Workplace?" Insight on the News, February 10, 1997. 